Сальнікова, С., Мурадян, О., Сидоров, М. (2020). Міжнародні макросоціальні показники як аналітичні інструменти в соціології. Соціологічні студї, 2 (17), 41-54. DOI: 10.29038/2306-3971-2020-02-41-54

\title{
Міжнародні макросоціальні показники як аналітичні інструменти в соціології
}

\section{Світлана Сальнікова -}

канд. сой. наук, доцент кафедри методології та методів сочіологічних досліджень, Київський начіональний університет ім. Тараса Шевченка, Украӥна

\section{Svitlana Salnikova -}

PhD in Sociology, Associate Professor, Department of Methodology and Methods of Sociological Research, Taras Shevchenko National University of Kyiv, Ukraine

E-mail: sv.salnikova@gmail.com ORCID: https://orcid.org/0000-00016368-9480

\section{Олена Мурадян -}

канд. сои. наук, доцент, декан соиіологічного факультету,

Харківський начіональний університет ім. В. Н. Каразіна, Украӥна

\section{Olena Muradyan -}

PhD in Sociology, Associate Professor, Dean of the School of Sociology, V. N. Karazin Kharkiv National University, Ukraine

E-mail: o.s.muradyan@karazin.ua ORCID: https://orcid.org/0000-00030990-9635

\section{Микола Сидоров -}

канд. фіз.-мат. наук, доиент, зав. кафедри методології та методів сочілологічних досліджень, Київський національний університет ім. Тараса Шевченка, Украӥна

\section{Mykola Sydorov -}

PhD in Mathematics, Associate Professor, Head of the Department of Methodology and Methods of Sociological Research, Taras Shevchenko National University of Kyiv, Ukraine

E-mail: myksyd@knu.ua

ORCID: https://orcid.org/0000-00025333-8393

DOI: 10.29038/2306-3971-2020-02-41-54

Reseived: September, 2020

$1^{\text {st }}$ Revision: October, 2020

Accepted: November, 2020
У статті розглянуто низку ініційованих міжнародними інституціями проєктів, які є джерелом системи показників для порівняльного вивчення суспільств(-а) на глобальному рівні, а також розширюють спектр методичних й аналітичних інструментів у соціології. Виокремлено певні обмеження в процесі використання даних міжнародних порівняльних проєктів, як-от: порівнюваність, інтерпретація та рейтингування. Обмеження спричинені соціальнокультурними відмінностями країн, відсутністю єдиної системи фіксації статистичних даних у державах, різною кількістю країн-учасниць проєктів, варіативністю джерел первинних даних для обчислення індексів. До означених причин варто додати й політичну ситуацію в державі.

Аналіз даних на рівні окремої країни потребує розгляду даних за всі роки їі участі в проєкті та обов'язкове звернення до змістового наповнення індексу та його складових частин.

Цінність дослідження полягає також в акумуляції електронних посилань про міжнародні проєкти в межах одного джерела, що спрощує пошук необхідної інформації. Проте кількість і тематична варіативність міжнародних макросоціальних показників $\epsilon$ значно більшою, тож перспективи цього дослідження полягають у розширенні їх кола, детальному аналізі окремих інституцій i/aбо проєктів, які їх конструюють; тематичних наукових дослідженнях із використанням макросоціальних показників.

Ключові слова: відкриті дані, вторинні дані, Big Data, індекс, міжнародний проєкт. 
Salnikova Svitlana, Muradyan Olena, Sydorov Mykola. International Macrosocial Indicators as Analytical Tools in Sociology. The article considers a number of projects initiated by international institutions, which are a source of a system of indicators for the comparative study of societies at the global level, as well as expand the range of methodological and analytical tools in sociology. In particular, World Giving Index from Gallup and Charities Aid Formation, and Wellcome Global Monitor from Gallup and Wellcome Trust, both Global Corruption Barometer and Corruption Perception Index from Transparency International, two economic indicators - Economic Freedom of the World, and Index of Economic Freedom - from The Cato Institute, Fraser institute, and The Heritage Foundation respectively, Human Development Index and Gender Social Norms Index from The United Nation, Global Peace Index and Global Terrorism Index from Institute for Economics \& Peace, Vision of Humanity are considered.

The authors identify the following limitations in the use of data from international comparative projects comparability, interpretation and ranking. The limitations are caused by socio-cultural differences of countries, the lack of a single system for recording statistics in all countries, the different number of countries participating in projects, the variability of primary data sources for the calculation of indices. The specific political situation in the state should be attached to these reasons. The analysis of macro-social indicators at the country level needs to consider data for all years of the participation of country in the project and mandatory appeal to the semantic content index and its components.

The value of this study is also in the accumulation of electronic links to international projects within a single source, which simplifies the search for the necessary information. However, the number and thematic variability of international macro-social indicators are much greater, so the prospects of this study are to expand their number, and detailed analysis of individual institutions and / or projects that design them, and thematic research using macro-social indicators.

Key words: open data, secondary data, Big Data, index, international project.

Сальникова Светлана, Мурадян Елена, Сидоров Николай. Международные макросоциальные показатели как аналитические инструменты в социологии. В статье рассматривается ряд инициированных международными институциями проектов, которые являются источником системы показателей для сравнительного изучения обществ(-а) на глобальном уровне, увеличивают спектр методических и аналитических инструментов в социологии. Указывается на некоторые ограничения соответствующих данных, а именно: сравнимость, интерпретация и рейтингование. Анализ данных на уровне отдельной страны требует также учитывать данные за все года ее участия в проекте и их содержательное наполнение как индекса в целом, так и его составных показателей.

Ценность этого исследования - в наличии проектов и ссылок на эти проекты в одном источнике. Тем не менее, всех международных проектов оно не покрывает, поэтому перспектива исследования состоит в расширении круга проектов, детального анализа отдельных проектов, тематических научных исследованиях с использованием международных макропоказателей.

Ключевые слова: открытые данные, вторичные данные, Big Data, индекс, международный проект.

Вступ. Глобалізація посприяла відкритості суспільств. Розвинені країни першими ініціювали тематичні дослідницькі проєкти за участі багатьох держав континенту й навіть світу. Частина проєктів - це порівняльні міжнародні дослідження, які збирають інформацію соціологічними засобами, $\epsilon$ безцінним джерелом первинних і вторинних соціологічних даних, на сьогодні вже посіли чільне місце $\mathrm{i}$ як навчальний матеріал, і як дослідницький інструмент, і як значуща інформація під час прийняття управлінських рішень. Колекцію таких проєктів зібрано в статті О. Мурадян та І. Тітаря «Порівняльні міжнародні дослідження і Україна: доступ до безцінного» (Мурадян, Титарь, 2010), продовження теми - у детальному представленні окремих проєктів (Мурадян, Титарь, 2011).

Інша частина проєктів грунтується на зборі соціологічної й/або статистичної інформації, яка інтегрується в певний(-і) індекс(-и); індекси позиціонуються як обгрунтований порівняльний інструмент вимірювання тих чи інших видів змін. Фактично весь подібний проєкт спрямований на збір великої кількості показників, переважно 3 відкритих джерел, за якими вибудовується набір міжнародних макросоціальних показників. Проєкти користуються популярністю в публічному просторі, ЗМІ, громадських організаціях, викликають безпосередній інтерес для політиків, урядовців, інвесторів, науковців, у тому числі соціологів.

Мета цієї статті - представлення міжнародних проєктів, які продукують макросоціальні показники, а також їх типологія за ознаками даних, які вони пропонують у відкритому доступі. 
Виклад основного матеріалу. Практики моніторингу різних сфер життя є усталеними для розвинених країн. Вони фактично вибудували цілу систему соціальних показників, які уможливили вивчення й прогнозування соціальних явищ і процесів, напрацювання управлінських рішень та інформаційну підтримку під час їх прийняття. Можна підсумувати основну мету таких проєктів - це прийняття управлінських рішень; задля цього збираються та обробляються різні показники: соціологічні й статистичні, у тому числі демографічні та економічні.

Поширення проєктів на міжнародний рівень не лише надало додаткових можливостей, а й зумовило певні обмеження.

Обмеження пов'язані з основними проблемами міжнародних порівняльних проєктів - це порівнюваність та інтерпретачія результатів.

Зазначені проблеми зумовлені тим, що не існує обгрунтованих критеріїв і показників, спроможних ураховувати всю соціально-культурну особливість різних країн і культур, з одного боку, та єдиної системи фіксації статистичних даних - 3 іншого.

До обмежень додано проблему рейтингування, зокрема «обгрунтовано неспроможність порівняння рейтингових місць країн через (1) різну кількість країн-учасниць у кожній хвилі й (2) відсутність критеріїв належності держави до певного рангу з урахуванням помилки вимірювання» (Сальнікова, 2014, с. 39).

Для науковців, зокрема соціологів, такі проєкти є (1) джерелом системи показників, котрі уможливлюють порівняльне вивчення суспільств(-а) на глобальному рівні, а також розширюють (2) спектр методичних та аналітичних інструментів, адже пропонують методику вимірювання показника й можуть слугувати основою для конструювання нових підходів до вимірювання складних концептів.

\section{Міжнародні інституції та ініційовані ними проєкти}

Міжнародна неурядова організація «Transparency International» (див. додаток табл. 1) проводить два потужних проєкти з вивчення корупції, їх можна знайти в розділах:

Основна (About) - Що ми робимо (What we do) - Дослідження (Research):

1) індекс сприйняття корупції (Corruption Perception Index, CPI) - це найбільш широко використовуваний показник корупції у світі. Корупція інтерпретується як зловживання довіреною владою для особистих вигод, тож індекс оцінює й ранжує країни-учасниці проєкту на основі того, наскільки корумпованим є державний сектор країни. Методика побудови індексу є комплексною, адже потребує надійних даних, зібраних різними визнаними організаціями; а індекс $є$ сумарним показником за тринадцятьма вимірами та оцінками корупції; значення індексу варіююється від 0 - дуже високий рівень корупції до 10 - корупція практично відсутня. Оскільки зміни рівня корупції є малопомітними (або тривалими в часі), індекс сприйняття корупції станом на поточний рік будується на основі усереднених даних, зібраних протягом останніх трьох років. Тож можна стверджувати, що показник корупції дає уявлення не стільки про поточний рівень корупції, скільки про його динаміку.

Які дані пропонує нам проєкт? По-перше, це загальний огляд щорічних результатів (вкладка Overview); по-друге, це дані щодо окремих 180-ти країн i/або років у вигляді карти світу, графіка або в табличному форматі. Останній можна безкоштовно завантажити у форматі Excel (вкладка Results). Цікавими є матеріали у вкладці Press\&downloads (повний звіт, карти, інфографіка).

Обравши у вкладці «Результати» Україну (див. рис. 1), ми отримали 126 (зі 198-ми) рейтингове місце з 30-ма балами (зі 100 можливих); Україна понизила своє рейтингове місце на декілька позицій; динаміку за 2012-2019 pр. подано на графіку (із 26 у 2012 р. до 30 балів у 2019 р. відповідно);

2) барометр глобальної корупції (Global Corruption Barometer, GCB) - це найбільше у світі опитування громадян про їхній безпосередній особистий досвід корупції в щоденному житті. Інформацію про методологію дослідження та опитувальник ${ }^{1}$ можна завантажити окремими документами; масив даних доступний у програмі Excel, проте завантажується не у звичній матричній формі даних.

\footnotetext{
${ }^{1}$ Див.: https://images.transparencycdn.org/images/Global_Corruption_Barometer_Core_Questionnaire2017.pdf
} 

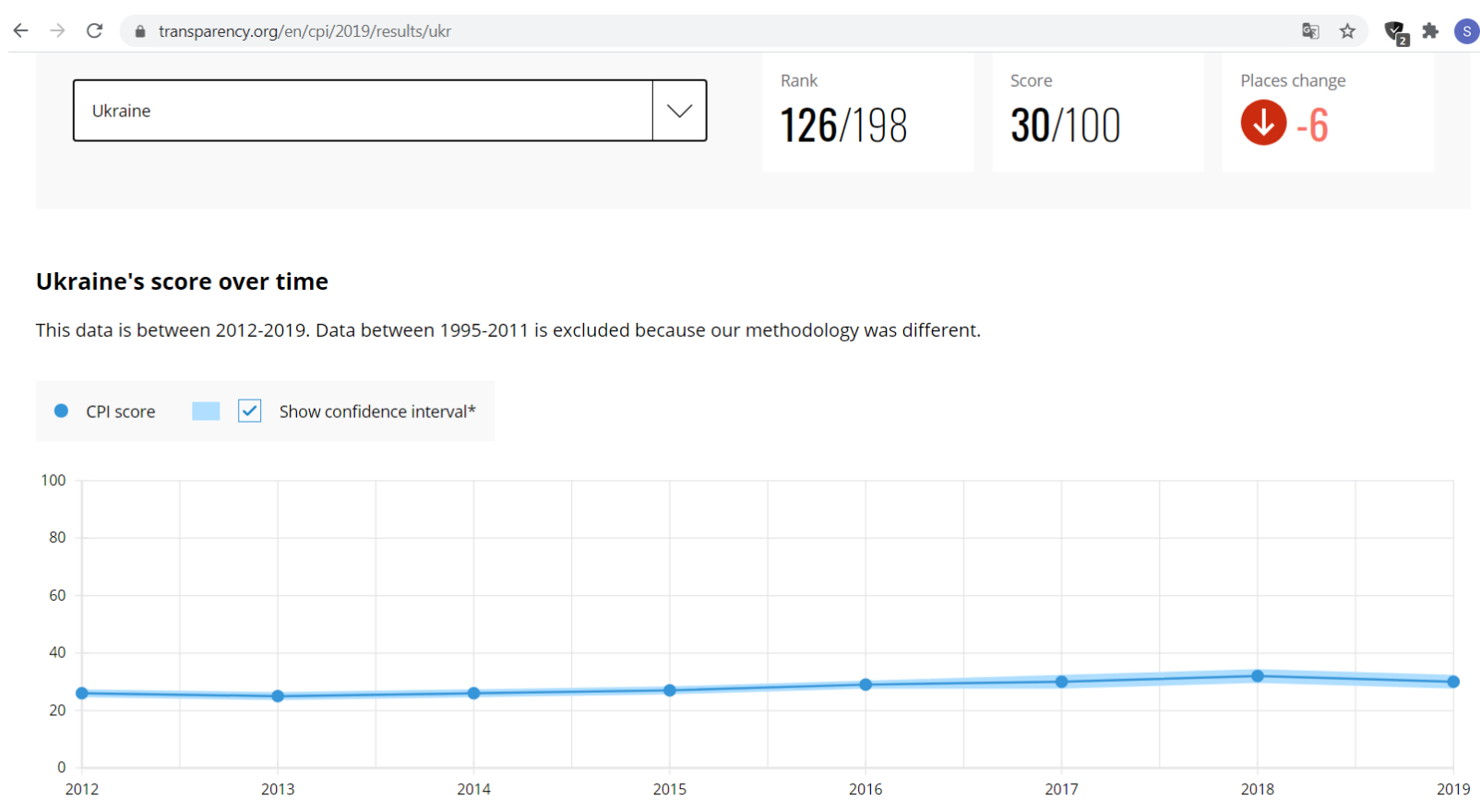

*The confidence interval reflects the variance in the value of the source data that comprise the CPI score.

Рис. 1. Індекс сприйняття корупиїі, Украӥна

Проскти Міжнародної дослідницької структури Інститут Геллапа (див. додаток табл. 1) Gallup World Poll - охоплюють понад 140 країн світу (це понад 95 \% населення планети); масштаб охоплення залежить від проєкту та років його проведення. Методологія збору даних і проєкти представлені на офіційному сайті інституту (Country Data Set Details, 2020; Global Research, 2020); більшість проєктів виконано у співпраці з іншими, профільними за тематикою дослідження, незалежними організаціями:

1) світовий індекс благодійності (World Giving Index, WGI) - проєкт, спрямований на надання «уявлення про природу благодійності й тенденції глобальної щедрості», проводиться спільно 3 Формацією благодійної допомоги (Charities Aid Formation, 2018). Індекс обчислюється як усереднений показник (\%) за трьома індикаторами: пожертва грошей на благодійність, участь у волонтерській діяльності, допомога незнайомим людям, котрі ії потребують.

На офіційному сайті проєкту можна скачати звіти з 2010 по 2018 р. 3 описом методології та аналізом даних або підписатися на їх безкоштовну розсилку. Працювати можна лише із вторинними даними, які згруповані для індексу загалом та трьох індикаторів зокрема, у розрізі країн-учасниць $\mathrm{i}$ таких соціально-демографічних ознак, як стать й освіта. Дані уможливлюють часові та просторові порівняння; задля уникнення впливу часових коливань індекс будується за окремо взятий рік та сумарно за останні п'ять років. Основні проблеми, у тому числі проблема рейтингування, описані в (Сальнікова, 2014). Проєкт цікавий не лише урядовим і неурядовим організаціям, науковці (Хом'як, 2015 та ін.) убачають у ньому цікаві дані для вивчення різних змін. Так, наприклад, найбільш вражаючою довгостроковою тенденцією $є$ стійке зростання індексів країн саме 3 перехідною економікою, тобто тих, які переживають бурхливий розвиток, але ще не віднесені до групи багатих;

2) Wellcome Global Monitor - проєкт, який вивчає ставлення громадськості до науки й здоров'я та проводиться спільно з організацією Wellcome (це незалежний благодійний фонд із повним ім'ям Wellcome Trust, який фінансує дослідницьку діяльність у сфері медицини). Основна мета проєкту полягає не лише в сприянні ефективним та цілеспрямованим політичним рішенням для покращення взаємодії громадськості з наукою й медициною, а спроможна допомогти фахівцям із врахуванням соціально-культурного контексту їхніх робіт, визначеністю локальних досліджень. Дані проєкту будуть цікаві тим, хто фокусує увагу на питаннях громадського здоров'я, зокрема вакцинації, 
впливовості фахових думок на щоденне життя пересічних громадян тощо. Осяжність проєкту доходить до 140 країн. У вільному доступі наявні методологія проєкту, анкета, набір даних і крос-таблиці для всіх країн у програмі Excel, а також цікава інфографіка на офіційному сайті.

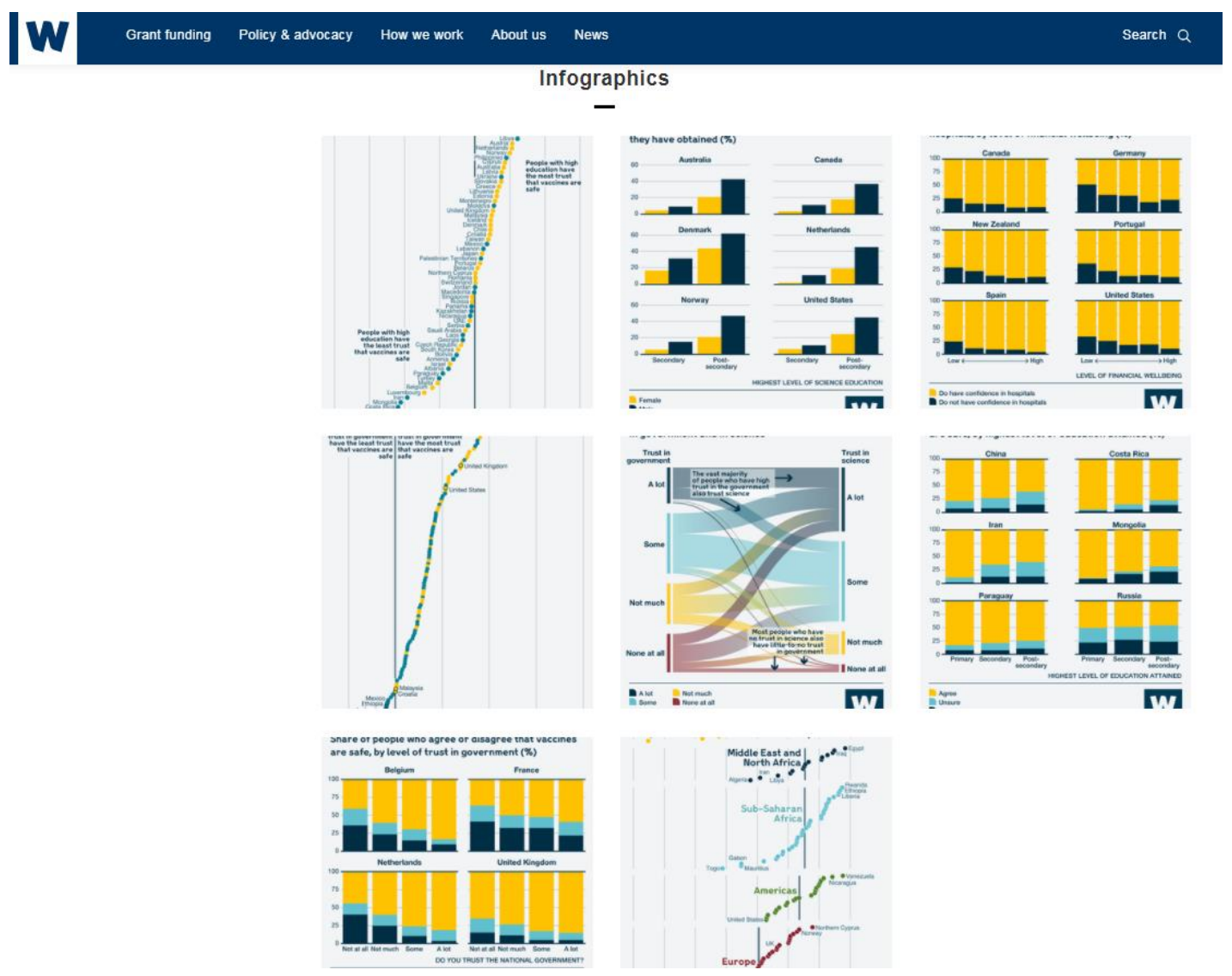

Рис. 2. Інфографіка проєкту «Welcome Global Monitor 2018»

Заслуговує на увагу індекс довіри до вчених (Trust in Scientists Index), який обчислюється як усереднений показник за п'ятьма індикаторами ${ }^{1}$, кожен із яких виміряний за 4-бальною шкалою довіри в порядку зростання (Wellcome Global Monitoring, p. 50-63). Аналіз даних виконано з урахуванням регіональної й соціально-економічної специфіки країн.

Індекс «Економічна свобода у світі» (Economic Freedom of the World, EFW) (див. додаток табл. 1) спрямований на вимірювання відповідності інститутів та політики країни економічній свободі, яка полягає в тому, що «держава повинна забезпечити надійний захист приватного майна, правову систему, що урівнює всіх, рівномірне виконання контрактів та стабільне грошове середовище. Вона також повинна знижувати податки, утримуватися від створення бар'єрів для як внутрішньої, так i міжнародної торгівлі, а також повніше покладатися на ринки, а не на державні витрати та регулювання для розподілу товарів і ресурсів» (Economic Freedom, 2011).

У вкладці Методологія $\epsilon$ опис концепту «економічна свобода»; індекс вимірює ступінь економічної свободи у п'яти сферах: розмір уряду (Size of Government), правова система та безпека майнових прав (Legal system\&property rights), доступ до грошей (Sound money), свобода міжнародної

${ }^{1} 1$ - How much do you trust scientists in this country? 2 - In general, how much do you trust scientists to find out accurate information about the world? 3 - How much do you trust scientists working for companies in this country to do their work with the intention of benefiting the public? 4 - How much do you trust scientists working in colleges/universities in this country to do their work with the intention of benefiting the public? 5 - How much do you trust scientists working in colleges/universities in this country to be open and honest about who is paying for their work? 
торгівлі (Freedom to trade internationally), регулювання кредитної політики, трудових стосунків i підприємницької діяльності (Regulation). Загалом індекс містить 44 індикатори 3 різних джерел (про спосіб обчислення, шкалу та джерело даних зазначено в додатку ${ }^{1}$ ), тож, власне, зі змістом цього документа потрібно ознайомитися першочергово. Значення індексу є усередненим показником із 10-бальною шкалою в порядку зростання. Значення кожного індикатора 3 аналогічною шкалою обчислюємо за формулою:

$$
10 \cdot\left(V_{\max }-V_{i}\right) /\left(V_{\max }-V_{\min }\right) \text {. }
$$

Звісно, варто скористатися повнотекстовими звітами, проте окремо хочеться звернути увагу на можливості роботи 3 даними на сайті. Інтерактивні карти візуалізують результати за весь період проєкту 1970-2020 (оприлюднення даних відбувається лише через два роки, останні дані презентовано восени 2020 р. $^{2}$ ), вибудовують рейтинг країн за обраним роком тощо. Графіки можна будувати для обраних країни й року, для кожної сфери індексу чи окремих сфер. Масиви даних можна завантажити в програмі Excel.

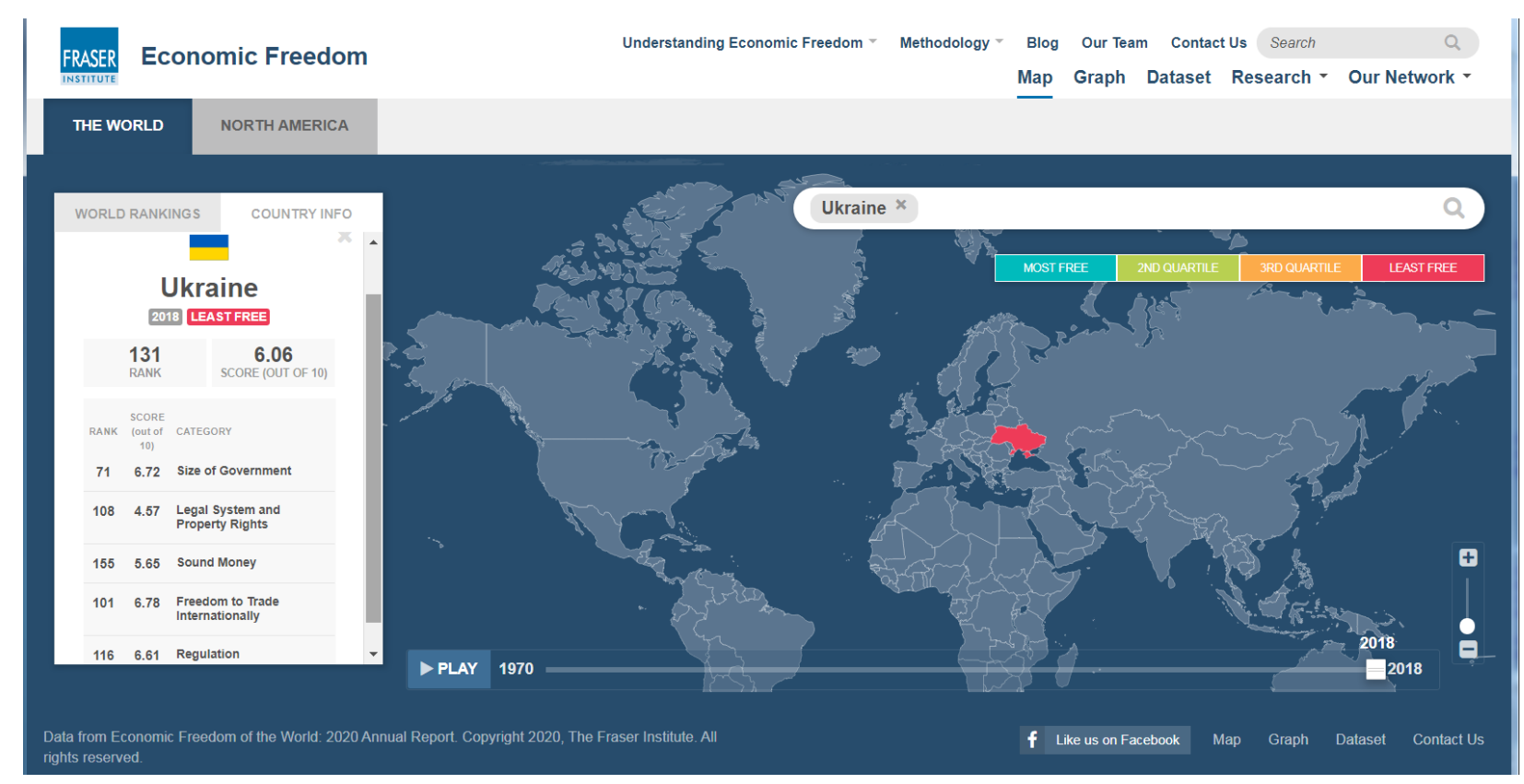

Рис. 3. Індекс «Економічна свобода у світі», Украӥна, 2019

Індекс економічної свободи (Index of Economic Freedom) (див. додаток табл. 1) від аналітичного центру The Heritage Foundation вимірюється на основі 12 кількісних і якісних показників, згрупованих у чотири категорії (див. рис. 4): 1 - верховенство права (право власності, непідкупність уряду, ефективність судової системи); 2 - розмір уряду (державні витрати, податкове навантаження, фіскальне благополуччя); 3 - ефективність регулювання (свобода бізнесу, свобода праці, монетарна свобода); 4 - відкриті ринки (свобода торгівлі, свобода інвестицій і фінансова свобода).

Кожен із 12 індикаторів оцінюється за шкалою від 0 до 100 балів. Індекс економічної свободи $є$ усередненим показником. Індекс та його складові показники інтерпретуються за 5-тибальною порядковою шкалою: 0-49,9 (репресована, repressed); 50-59,9 (переважно відсутня, mostly unfree); 6069,9 (помірна, moderately free); 70-79,9 (переважно присутня, mostly free); 80-100 (Free).

На офіційному інтерактивному сайті центру є такі можливості:

- теплова карта світу: вибір країни (або регіону) і року відразу презентує значення індексу економічної свободи та його складових показників, а відповідний колір маркує кожне значення показника за проміжком, до якого воно потрапляє;

\footnotetext{
${ }^{1}$ Див.: https://www.fraserinstitute.org/sites/default/files/economic-freedom-of-the-world-2019-appendix.pdf

2 Див.: https://www.fraserinstitute.org/sites/default/files/economic-freedom-of-the-world-2020.pdf
} 
- рейтинги 180 країн світу, назва кожної з них також є інтерактивною й презентує більш детальну інформацію про неї. Власне, із цієї опції ми дізналися, що економічна свобода в Україні переважно відсутня (віддамо належне постійному зростанню цього показника від 2016 р.), і в рейтингу 45-ти європейських країн держава Україна займає останню позицію (див. рис. 4, рис. 5);

- графіки для світу загалом чи окремих його частин/країн за період усього проєкту презентують цікаві тренди, що дає підставу прогнозувати подальший розвиток окремих країн;

- звіт у цілому або окремі його частини можна вільно завантажити.

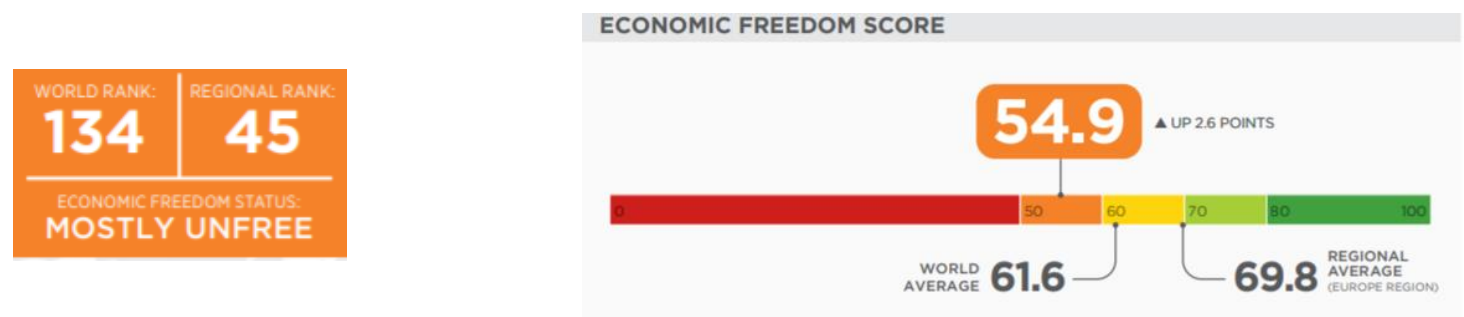

Рис. 4. Індекс економічної свободи, Україна

\begin{tabular}{|c|c|c|c|}
\hline Previous: \#133 Benin & & & Next: \#135 Pakistan > \\
\hline OVERALL SCORE $\mathbf{5 4 . 9}$ & & & WORLD RANK 134 \\
\hline RULE OF LAW & & GOVERNMENT SIZE & \\
\hline Property Rights & $47.5 \wedge$ & Tax Burden & $81.1 \checkmark$ \\
\hline Judicial Effectiveness & $42.2 \wedge$ & Government Spending & $47.2 \wedge$ \\
\hline Government Integrity & $37.9 \wedge$ & Fiscal Health & $83.9 \wedge$ \\
\hline REGULATORY EFFICIEI & & OPEN MARKETS & \\
\hline Business Freedom & $61.3 \vee$ & Trade Freedom & 81.2 人 \\
\hline Labor Freedom & $48.3 \wedge$ & Investment Freedom & $35.0-$ \\
\hline Monetary Freedom & $63.0 \wedge$ & Financial Freedom & $30.0-$ \\
\hline
\end{tabular}

Рис. 5. Індекс економічної свободи та його показники, Украӥна

Індекс людського розвитку (Human Development Index, HDI) (див. додаток табл. 1) - один із найбільш відомих проєктів Всесвітнього банку, який демонструє рівень благополуччя населення в кожній країні, у тому числі можливості для реалізації життєвих потреб і пріоритетів. Це комплексна порівняльна оцінка розвитку держав й окремих регіонів.

ІЛР - це комбінований показник, побудований на основі 3-х окремо розрахованих індексів. Критеріями людського розвитку є очікувана тривалість життя, два показники освіти - очікувані та середні роки навчання, дохід на душу населення за паритетом купівельної спроможності (рис. 5). Іншими словами, ідеться про здорове життя, високий рівень освіти й гідний рівень життя (рис. 6).

Для побудови ІЛР значення індикаторів нормалізують. Отже, усереднений ІЛР за унормованими значеннями 3-х показників змінюється від 0 до 1: значення 0,8 і більше означає високий рівень розвитку людського потенціалу, від 0,5 до 0,8 - середній, менше 0,5 - низький.

Дані цього дослідження показують, що індекс людського розвитку в Україні за останні 10 років не покращився; однак показник України вищий за показники в інших країнах із подібним рівнем економічного зростання.

ІЛР є основою для обчислення іншого показника - індексу гендерного розвитку людського потенціалу (Gender Development Index, GDI), - який вимірює гендерну нерівність у досягненнях у трьох основних сферах людського розвитку - здоров’я (співвідношення очікуваної тривалості життя серед жінок та чоловіків під час народження), освіта (співвідношення очікуваної тривалості навчання для дітей і дорослих віком від 25 років), можливість вільно розпоряджатися наявними економічними 
ресурсами (вимірюється очікуваним валовим національними доходом на душу населення для чоловіків та жінок). Обчислюють індекс людського розвитку окремо для чоловіків і жінок за такими формулами:

$$
\begin{aligned}
& H D I_{f}=\frac{1}{3}\left(H D I_{\text {Health }_{f}} \times H D I_{\text {Educationg }} \times H D I_{\text {Income }_{f}}\right) \text {; } \\
& H D I_{m}=\frac{1}{3}\left(H D I_{\text {Health }_{1 m}} \times H D I_{\text {Edueation }_{12}} \times H D I_{\text {Income }_{1 \pi}}\right) \text {. }
\end{aligned}
$$

Тоді ІГРЛП - це відношення ІЛР (HDI), обчислених для кожної статі:

$$
G D I=H D I_{f} / H D I_{m} \text {. }
$$
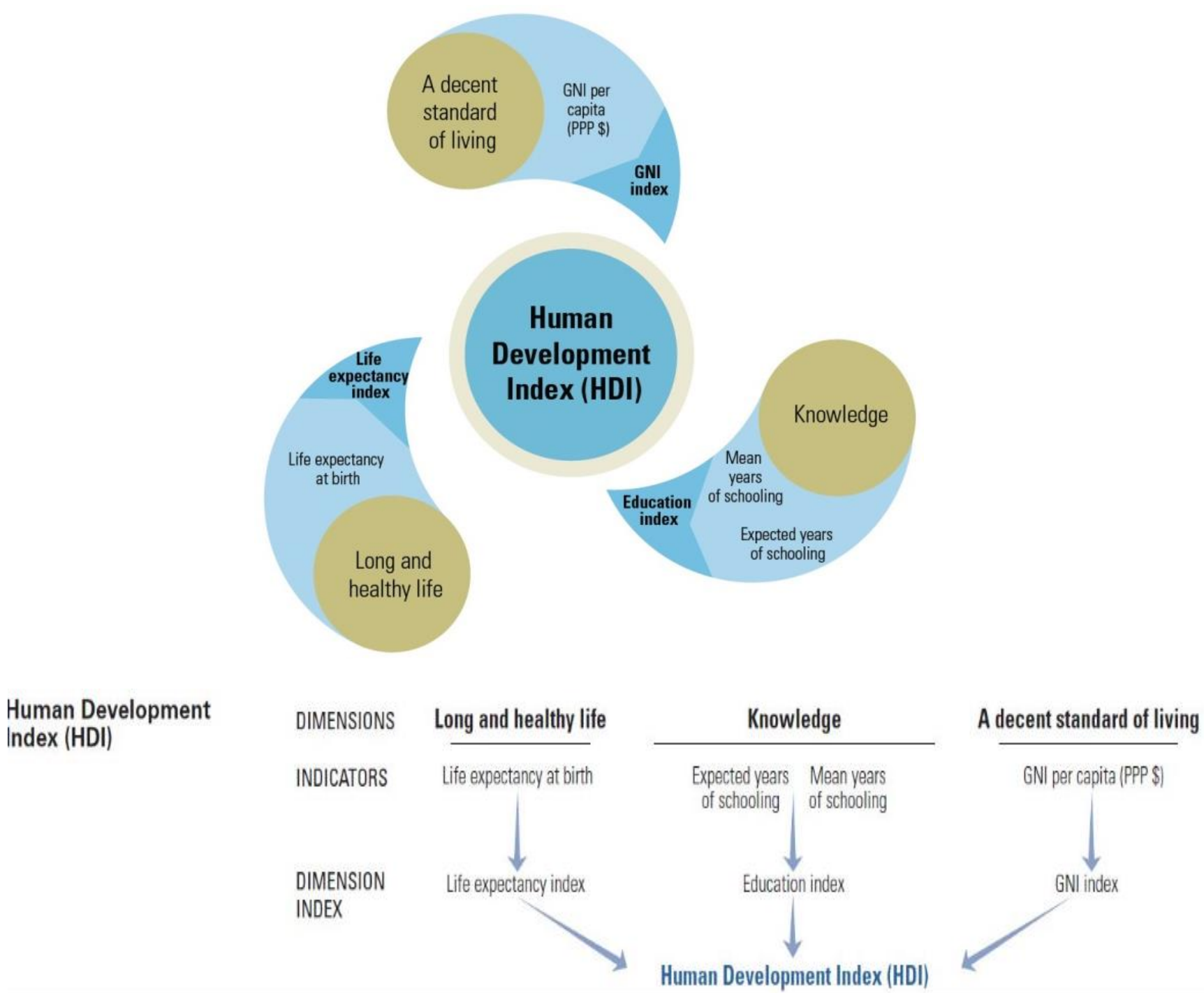

Рис. 6. Структура індексу людського розвитку, http://hdr.undp.org/en/content/human-development-index-hdi

У 2010 р. ООН уперше презентувала індекс багаторівневої бідності (Multidimensional Poverty Index, MPI), звіт, як і їх решта, - у вільному доступі. Цей індекс замінив індекс бідності населення, який використовувався до 2009 р. і слугує доповненням до ІЛР. Важливим моментом є те, що підкреслюється недостатність урахування лише індикаторів доходу, тому враховується включеність у сферу освіти (тривалість навчання, відвідування школи дітьми), здоров'я (дитяча смертність, харчування), стандарти життя (санітарія, електрика, питна вода, якість підлоги, паливо для приготування їжі, наявність і розміри активів у володінні). Бідність населення розглядається крізь призму проблем, пов'язаних із низьким рівнем соціального захисту, не лише економічною, а й соціальною нерівністю, 
зростанням злочинності - усе це є взаємопов'язаними й взаємодоповнюваними проблемами у всіх регіонах світу.

Повну інформацію - від звітів до даних - про індекс гендерних соціальних норм (Gender Social Norms Index, GSNI) можна знайти на офіційному сайті. Структуру індексу представлено на рис. 7. Зазначимо, що цей індекс демонструє негативну реакцію на явний прогрес у встановленні гендерного балансу. Так, у половині оцінених країн по всьому світу збільшилися прояви гендерних упереджень (Human Development Perspectives, 2020).

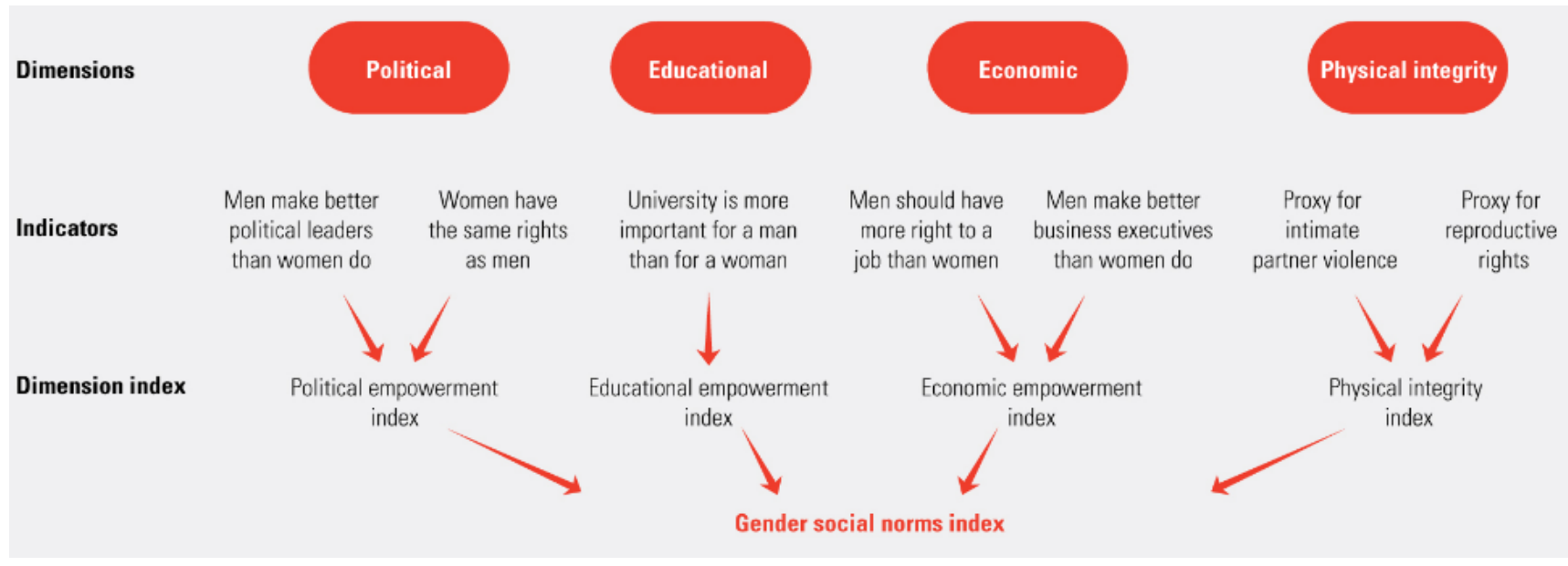

Рис. 7. Структура індексу гендерних соиіальних норм, http://hdr.undp.org/en/gsni

Програмою ООН передбачено рейтингування країн за ІЛР, проте у відповідній таблиці на сайті містяться також показники тривалості життя, освіти й доходу та можливість сортування даних за зазначеними показниками, якщо обрати заголовок відповідного стовпця.

Організація Об'єднаних Націй збирає статистичну інформацію й конструює інші показники. Тож їх можна отримати у вкладці «Дані» (Data). Корисним є інструмент «Обчислення індексів» (Culculating the Indexis): у програмі Excel запрограмовані формули для обчислення індексу людського розвитку (ІЛР) і його складників, ІЛР із поправкою на нерівність (ІЛРН), індексу гендерної нерівності (IГН), індексу гендерного розвитку людського потенціалу (ІГРЛП), які можна вільно скачати.

Працювати з усім набором даних для окремо взятої країни можна через вкладку «Профіль країни» (Country Profiles).

Глобальний індекс миролюбності (Global Peace Index, GPI) вимірює Інститут економіки і миру (див. додаток, табл. 1), на сайті інституту в розділі «Дослідження» (Research) наявні повні звіти за 2019 i $2020^{1}$ pp. для 163 держав світу. Започаткована ним програма Vision of Humanity (Бачення людства), у рамках якої виконується дослідження, має окремий сайт.

Індекс характеризується трьома вимірами른

- тривалого внутрішнього та міжнародного конфлікту (Measures of ongoing domestic and international conflict);

- соціального захисту й безпеки в країні (Measures of safety and security in countries);

- мілітаризації держави (Militarization).

Частина індикаторів оцінюється за 5-тибальною шкалою в порядку зростання; індикатори забсолютними показниками зводяться до 5-тибальної шкали через перетворення $5 \cdot\left(V_{i}-V_{\max }\right) /\left(V_{\max }-V_{\min }\right)$, де максимальне та мінімальне значення індикатора визначаються серед повного переліку держав-учасниць. Глобальний індекс миролюбності $є$ усередненим показником зважених індикаторів (Global Peace Index..., 2020, p. 88-95).

\footnotetext{
${ }^{1}$ Див.: https://www.economicsandpeace.org/wp-content/uploads/2020/08/GPI_2020_web-1.pdf

2 Див. індикатори: https://web.archive.org/web/20080512222129/http:/www.visionofhumanity.com/GPI_Indicators/index.php
} 


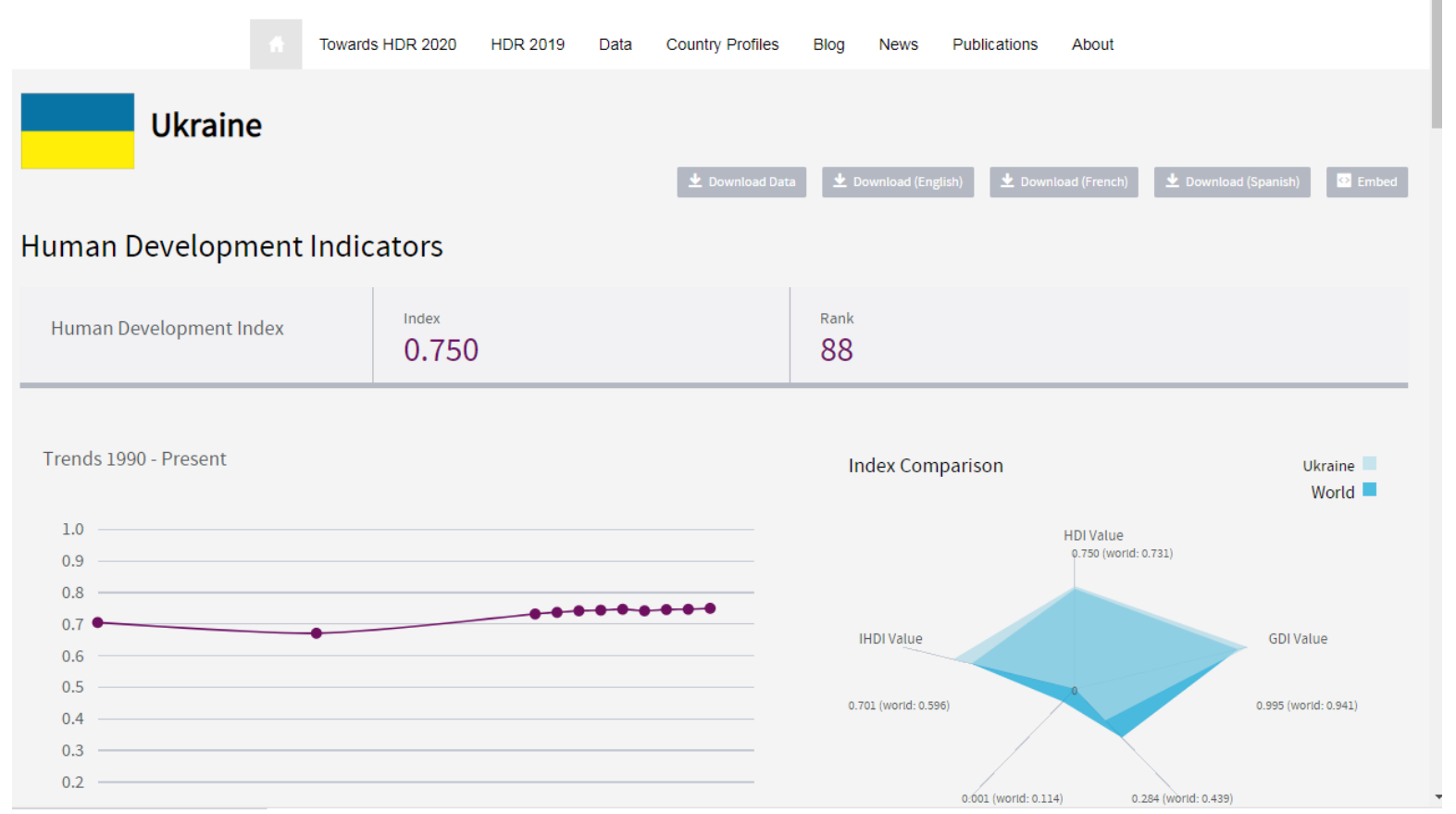

Рис. 8. Індикатори індексу людського розвитку, Украӥна, 2020, http://hdr.undp.org/en/countries/profiles/UKR\#

Вкладка «Карти і Дані» (Maps\&Data) дає можливість попрацювати 3 інтерактивною картою (див. рис. 9; 10).

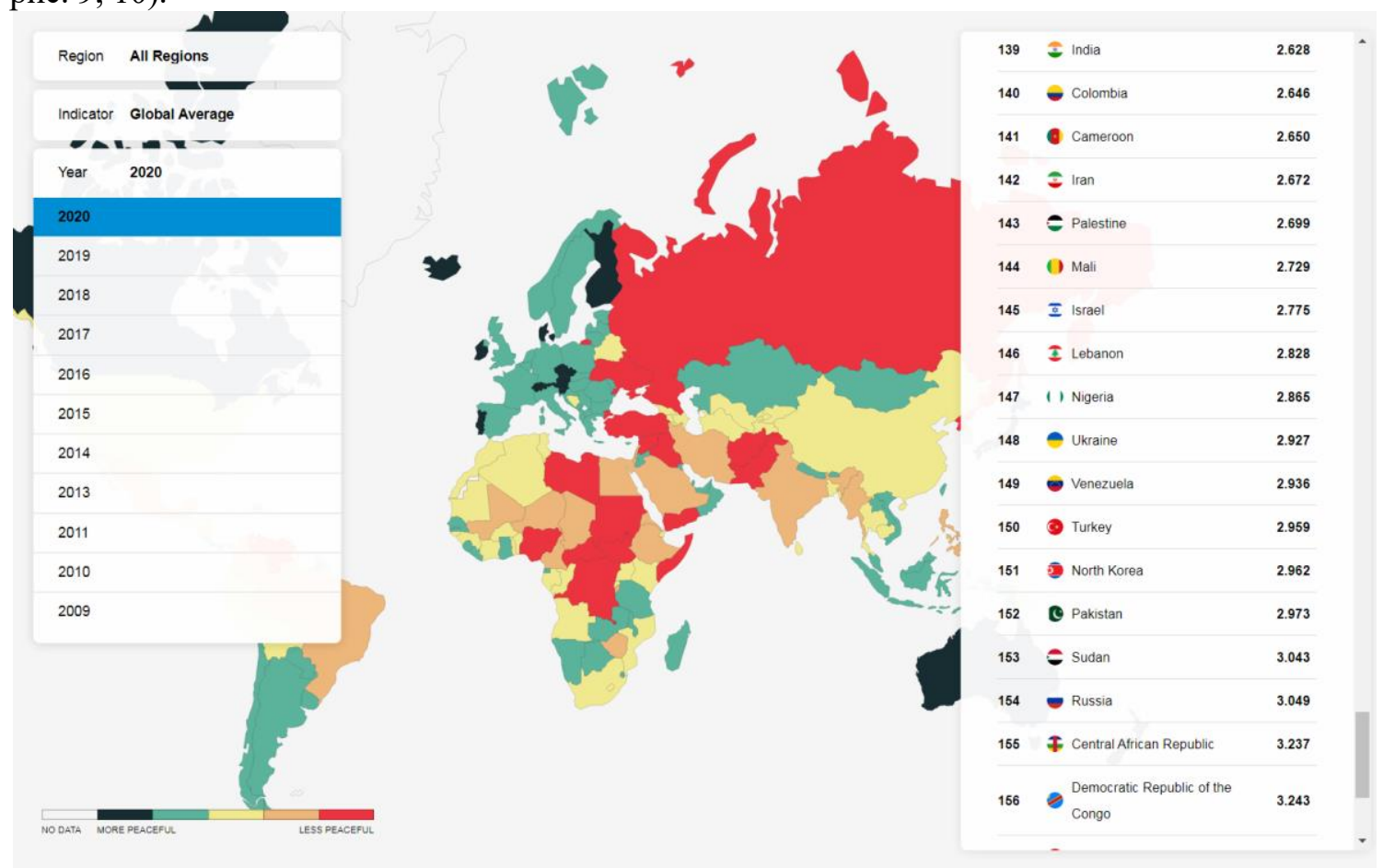

Рис. 9. Глобальний індекс миролюбності, інтерактивна карта, https://www.visionofhumanity.org/maps/\#/ 


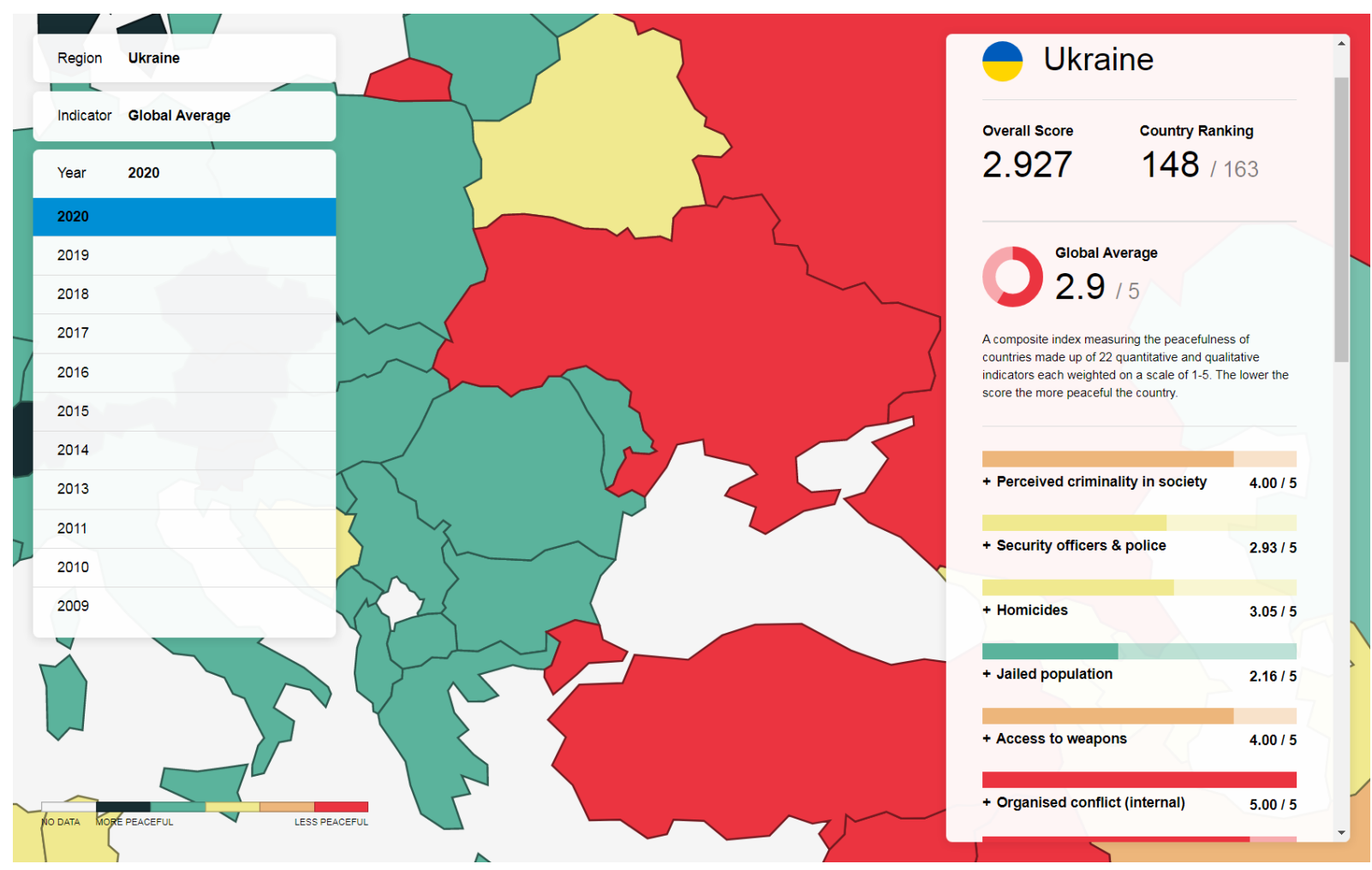

Рис. 10. Глобальний індекс миролюбності, Украӥна, https://www.visionofhumanity.org/maps/\#/

У 2020 р. Інститут економіки і миру презентував видання ${ }^{1} 3$ вимірювання глобального індексу тероризму (Global Terrorism Index, GTI), у якому також представлено його методологію (Global Terrorism Index..., 2020, p. 96-97).

Розрахунки виконують на основі інформації з глобальної бази даних тероризму (Global Terrorism Database $^{2}$, GTD) Національного консорціуму з вивчення тероризму при Університеті штату Меріленд (START Center at the University of Maryland), що на сьогодні $\epsilon$ найбільшою у світі статистичною базою про терористичну діяльність, котра містить інформацію про більш ніж 150 тисяч випадків терористичних актів за останні роки. Використовуються чотири показники за один досліджуваний рік: загальна кількість терористичних інцидентів, загальна кількість загиблих жертв тероризму, загальна кількість постраждалих (травмованих), від тероризму, рівень загального матеріального збитку від терористичних актів. Побудова рейтингу здійснюється за 10-бальною шкалою - від 0 (нульове значення) до 10 (максимальний рівень тероризму). Це дає змогу супроводжувати індекс рейтингом країн світу за рівнем тероризму. Останнє дослідження охопило 163 держави. Його дані оприлюднено в листопаді 2020 p.

Висновки та перспективи подальших досліджень. У статті розглянуто низку ініційованих міжнародними інституціями проєктів (див. додаток, табл. 1), які є значимим джерелом макросоціальних показників у соціології, методичних й аналітичних інструментів їх конструювання.

Інтерес авторів до означеної теми грунтується також на практичній потребі застосування цих міжнародних проєктів у викладанні навчальних дисциплін, пов'язаних із порівняльною соціологією, методиками вимірювання складних показників, роботою з великими даними тощо. Вичерпати тему в межах однієї публікації неможливо, адже перелік міжнародних проєктів є значно більшим. Тож існує перспектива «розширити коло розглядуваних проєктів», здійснити їх «детальний аналіз» (Мурадян, Титарь, 2010, с. 153) чи тематичні дослідження з використанням відповідних даних.

\footnotetext{
${ }^{1}$ Див.: https://www.visionofhumanity.org/wp-content/uploads/2020/11/GTI-2020-web-1.pdf

${ }^{2}$ Офіційний сайт: https://start.umd.edu/gtd/
} 


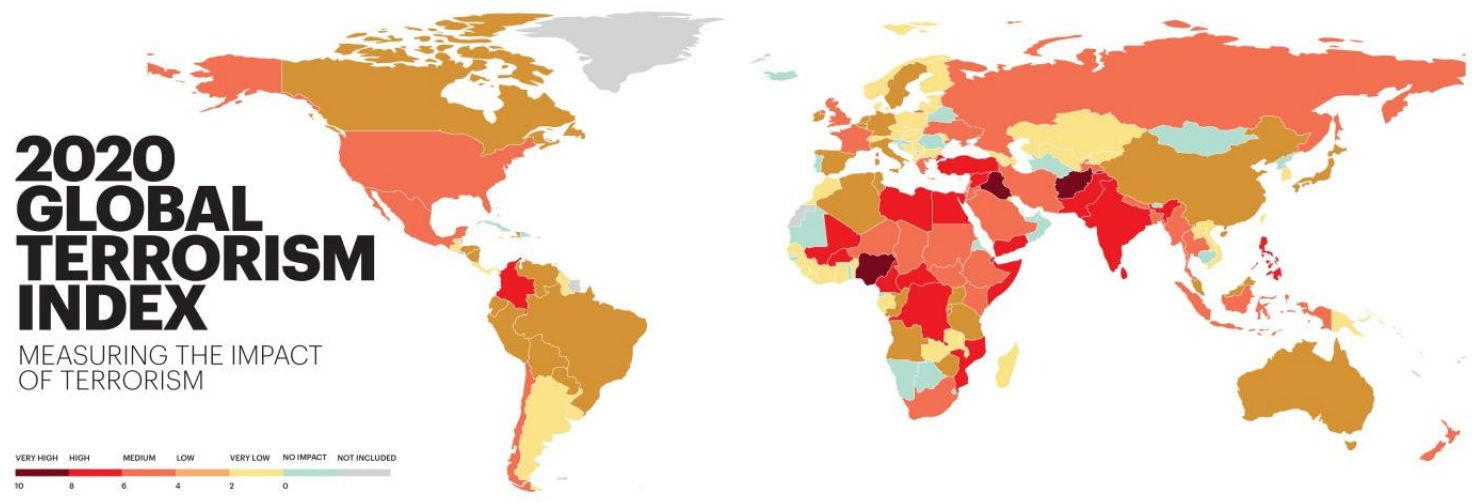

Рис. 11. Глобальний індекс тероризму, 2020

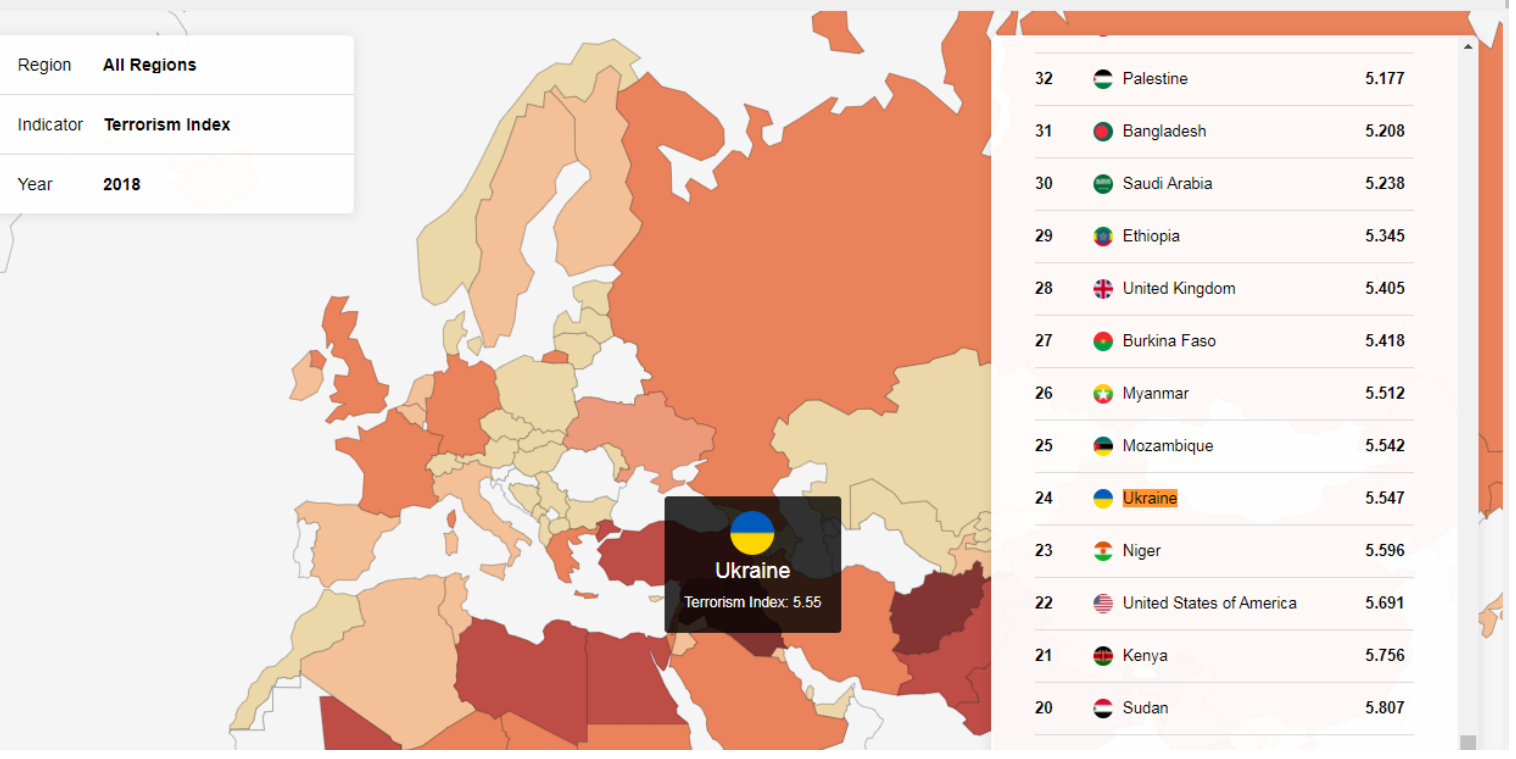

Рис. 12. Глобальний індекс тероризму, Украӥна, 2018, https://www.visionofhumanity.org/maps/global-terrorism-index/\#/

\section{Джерела та література}

1. Мурадян, Е. С., Титарь, И. А. (2010). Сравнительные международные исследования и Украина: доступ к бесценному. Междисциплинарный сборник научных работ по социологии и социальной работе, № 1(10), 143-155. Получено 10 мая 2020. http://www.sociology.kharkov.ua/socioprostir/files/magazine/1_2010/3_1.pdf

2. Мурадян, Е. С., Титарь, И. А. (2011). Международные сравнительные исследования: «Вarometers» и «SHARE». Междисциплинарный сборник научных работ по сочиологии и сочиильной работе, № 2(11), 111-120. Получено 10 мая 2020. http://www.sociology.kharkov.ua/socioprostir/files/magazine/2_2011/3_1.pdf

3. Сальнікова, С. (2014). Благодійність населення східноєвропейських країн із радянським минулим. Сочіологічні студіï, 2(5), 39-45, https://sociostudios.vnu.edu.ua/index.php/socio/article/view/106/82

4. Хом'як, А. (2015). Участь населення України у волонтерській та благодійницькій діяльності. Соціологічні cmydiï, 2(7), 67-71. https://doi.org/10.29038/2306-3971-2015-02-67-71

5. Country Data Set Details (2020). Gallup. Retrieved September 4, 2020 from https://www.gallup.com/services/ 177797/country-data-set-details.aspx 
6. Economic Freedom (2020). Fraser Institute. Retrieved September 13, 2020 from https://www.fraserinstitute.org/ economic-freedom/economic-freedom-basics

7. Global Peace Index 2020: Measuring Peace in a Complex World (2020). Institute for Economics \& Peace. Sydney. Retrieved June 30, 2020 from http://visionofhumanity.org/reports

8. Global Research (2020). Gallup. Retrieved September 4, 2020 from https://www.gallup.com/analytics/ 318875/global-research.aspx

9. Global Terrorism Index 2020: Measuring the Impact of Terrorism (2020). Institute for Economics \& Peace. Sydney. Retrieved November 12, 2020 from http://visionofhumanity.org/reports

10. Human Development Perspectives 2020. Tackling social norms - a game changer for gender inequalities. Retrieved September 16, 2020 from http://hdr.undp.org/sites/default/files/hd_perspectives_gsni.pdf

11. Wellcome Global Monitoring 2018. How does the world feel about science and health? (2019). Gallup. Retrieved September 14, 2020 from https://wellcome.org/sites/default/files/wellcome-global-monitor-2018.pdf

\section{References}

1. Country Data Set Details (2020). Gallup. Retrieved September 4, 2020 from https://www.gallup.com/services/ 177797/country-data-set-details.aspx

2. Economic Freedom (2020). Fraser Institute. Retrieved September 13, 2020 from https://www.fraserinstitute.org/ economic-freedom/economic-freedom-basics

3. Global Peace Index 2020: Measuring Peace in a Complex World (2020). Institute for Economics \& Peace. Sydney. Retrieved June 30, 2020 from http://visionofhumanity.org/reports

4. Global Research (2020). Gallup. Retrieved September 4, 2020 from https://www.gallup.com/analytics/ 318875/global-research.aspx

5. Global Terrorism Index 2020: Measuring the Impact of Terrorism (2020). Institute for Economics \& Peace. Sydney. Retrieved November 12, 2020 from http://visionofhumanity.org/reports

6. Human Development Perspectives 2020. Tackling social norms - a game changer for gender inequalities. Retrieved September 16, 2020 from http://hdr.undp.org/sites/default/files/hd_perspectives_gsni.pdf

7. Khomiak, A. (2015). Participation of the Population of Ukraine in Voluntary and Charitable Activities. Sociological Studios. 2(7), 67-71. https://doi.org/10.29038/2306-3971-2015-02-67-71

8. Muradyan, O. S., Titar, I. A. (2010). Comparative International Researches and Ukraine: Access to the Invaluable. The Interdisciplinary Collection of Scientific works on Sociology and Social Work. No 1(10), 143155. Retrieved May 15, 2020. http://www.sociology.kharkov.ua/socioprostir/files/magazine/1_2010/3_1.pdf

9. Muradyan, O. S., Titar, I. A. (2011). International Comparative Researches: «Barometers» and «SHARE». The Interdisciplinary Collection of Scientific works on Sociology and Social Work. No 2(11), 111-120. Retrieved May 15, 2020. http://www.sociology.kharkov.ua/socioprostir/files/magazine/2_2011/3_1.pdf

10. Salnikova, S. A. (2014). The Charity of Population of East European Countries with the Soviet Past. Sociological Studios. 2(5), 39-45. https://sociostudios.vnu.edu.ua/index.php/socio/article/view/106/82

11. Wellcome Global Monitoring 2018. How does the world feel about science and health? (2019). Gallup. Retrieved September 14, 2020 from https://wellcome.org/sites/default/files/wellcome-global-monitor-2018.pdf

\section{Додаток}

Таблиия 1

Міжнародні проєкти, які є джерелами макросоціальних показників

\begin{tabular}{|c|c|c|c|c|}
\hline $\begin{array}{c}\text { Назва організації*, яка } \\
\text { проводить проєкт }\end{array}$ & $\begin{array}{c}\text { Період } \\
\text { проскту }^{1}\end{array}$ & Електронна адреса & $\begin{array}{c}\text { Джерела первинних } \\
\text { даних }\end{array}$ & $\begin{array}{r}\text { Доступ } \\
\text { до даних }\end{array}$ \\
\hline 1 & 2 & 3 & 4 & 5 \\
\hline \multirow{4}{*}{$\begin{array}{l}\text { Міжнародна неурядова } \\
\text { організація «Transpa- } \\
\text { rency International» }\end{array}$} & \multicolumn{4}{|c|}{ Барометр глобальної корупції/Global Corruption Barometer (GCB) } \\
\hline & 2003-2017 & http://www.transparency.org & $\begin{array}{l}\text { Соціологічні } \\
\text { опитування }\end{array}$ & $\begin{array}{l}+, \\
\text { Вторин- } \\
\text { ні дані }\end{array}$ \\
\hline & \multicolumn{4}{|c|}{ Індекс сприйняття корупції/Corruption Perception Index (CPI) } \\
\hline & 1995-2019 & http://www.transparency.org & $\begin{array}{l}\text { Соціологічні } \\
\text { опитування, експертні } \\
\text { оцінки }\end{array}$ & $\begin{array}{l}\text { Вторин- } \\
\text { ні дані }\end{array}$ \\
\hline
\end{tabular}

${ }^{1}$ Під періодом проєкту зазначено рік його заснування та останній рік, дані за який представлені на офіційній сторінці організації-виконавця станом на листопад 2020 р. Більшість проєктів зазначають про період внутрішнього використання отриманих даних і вільний доступ до них опісля означеного періоду. 
Закінчення таблищі 1

\begin{tabular}{|c|c|c|c|c|}
\hline 1 & 2 & 3 & 4 & 5 \\
\hline \multirow[b]{2}{*}{$\begin{array}{l}\text { Інститут Геллапа } \\
\text { i британська } \\
\text { міжнародна благодійна } \\
\text { організація «Формація } \\
\text { благодійної допомоги» / } \\
\text { Gallup World View, } \\
\text { and Charities Aid } \\
\text { Formation }\end{array}$} & \multicolumn{4}{|c|}{ Світовий індекс благодійності/World Giving Index (WGI) } \\
\hline & $2010-2018$ & $\begin{array}{l}\text { http://www.cafonline.org/worldgivin } \\
\text { gindex } \\
\text { http://futureworldgiving.org }\end{array}$ & $\begin{array}{l}\text { Соціологічні } \\
\text { опитування }\end{array}$ & $\begin{array}{l}\text { Вторин- } \\
\text { ні дані }\end{array}$ \\
\hline \multirow{2}{*}{$\begin{array}{l}\text { Інститут Геллапа } \\
\text { i британський } \\
\text { незалежний } \\
\text { благодійний фонд } \\
\text { «Велкам» / Gallup, } \\
\text { and Wellcome Trust }\end{array}$} & \multicolumn{4}{|c|}{$\begin{array}{l}\text { Wellcome Global Monitor/Глобальний моніторинг Велкам } \\
\text { [Індекс довіри до вчених (Trust in Scientists Index)] }\end{array}$} \\
\hline & $2005-2018$ & $\begin{array}{l}\text { https://wellcome.org/reports/wellco } \\
\text { me-global-monitor/2018 }\end{array}$ & $\begin{array}{l}\text { Соціологічні } \\
\text { опитування }\end{array}$ & $\begin{array}{l}\text { Вторин- } \\
\text { ні дані }\end{array}$ \\
\hline \multirow[b]{2}{*}{$\begin{array}{l}\text { Інститут Катона, } \\
\text { Інститут Фрезера, } \\
\text { Канада / The Cato } \\
\text { Institute, Fraser institute, } \\
\text { Canada }\end{array}$} & \multicolumn{4}{|c|}{ Індекс «Економічна свобода у світі»/Economic Freedom of the World (EFW) } \\
\hline & $1975-2020$ & http://www.freetheworld.com/ & $\begin{array}{l}\text { Статистичні та } \\
\text { соціологічні дані } \\
\text { незалежних опитувань } \\
\text { у країні }\end{array}$ & $\begin{array}{l}\text { Вторин- } \\
\text { ні дані }\end{array}$ \\
\hline \multirow{2}{*}{$\begin{array}{l}\text { Аналітичний центр } \\
\text { «Фонд спадщини» / The } \\
\text { Heritage Foundation } \\
\end{array}$} & \multicolumn{4}{|c|}{ Індекс економічної свободи/Index of Economic Freedom } \\
\hline & $1995-2020$ & https://www.heritage.org/index/ & Статистичні дані & + \\
\hline \multirow{4}{*}{$\begin{array}{l}\text { Організація Об’єднаних } \\
\text { Націй (OOH)/The United } \\
\text { Nation (UN) }\end{array}$} & \multicolumn{4}{|c|}{ Індекс людського розвитку/Human Development Index (HDI) } \\
\hline & $1990-2020$ & http://hdr.undp.org/ & $\begin{array}{l}\text { Статистичні дані, } \\
\text { експертні оцінки }\end{array}$ & + \\
\hline & \multicolumn{4}{|c|}{ Індекс гендерних соціальних норм/Gender Social Norms Index (GSNI) } \\
\hline & $\begin{array}{l}2005-2009 \\
2010-2014\end{array}$ & http://hdr.undp.org/en/gsni & Статистичні дані & + \\
\hline \multirow[b]{2}{*}{$\begin{array}{l}\text { Інститут економіки і } \\
\text { миру, Бачення } \\
\text { людства/Institute for } \\
\text { Economics \& Peace } \\
\text { (IEP), Vision of } \\
\text { Humanity }\end{array}$} & \multicolumn{4}{|c|}{$\begin{array}{l}\text { Глобальний індекс миролюбності/Global Peace Index (GPI) } \\
\text { Глобальний індекс тероризму/Global Terrorism Index (GTI) }\end{array}$} \\
\hline & $\begin{array}{l}2009-2020 \\
2012-2020\end{array}$ & $\begin{array}{l}\text { https://www.economicsandpeace.org } \\
\text { / } \\
\text { https://www.visionofhumanity.org/r } \\
\text { esources/ } \\
\text { http://visionofhumanity.org/indexes/ } \\
\text { global-peace-index/ } \\
\text { https://web.archive.org/web/200805 } \\
\text { 12222129/http://www.visionofhuma } \\
\text { nity.com/GPI_Indicators/index.php }\end{array}$ & $\begin{array}{l}\text { Статистичні дані, } \\
\text { експертні оцінки }\end{array}$ & $\begin{array}{l}\text { Вторин- } \\
\text { ні дані }\end{array}$ \\
\hline
\end{tabular}

*міжнародні дослідницькі організації, наукові центри, університети. 